\title{
Diverse Elements in Herbal Tea Products Consumed in Serbia Using Inductively Coupled Plasma Mass Spectrometry
}

\section{Slavica Razic \& Vesna Kuntic}

To cite this article: Slavica Razic \& Vesna Kuntic (2013) Diverse Elements in Herbal Tea Products Consumed in Serbia Using Inductively Coupled Plasma Mass Spectrometry, International Journal of Food Properties, 16:1, 1-8, DOI: 10.1080/10942912.2010.526273

To link to this article: https://doi.org/10.1080/10942912.2010.526273

(2) Copyright Taylor \& Francis Group, LLC

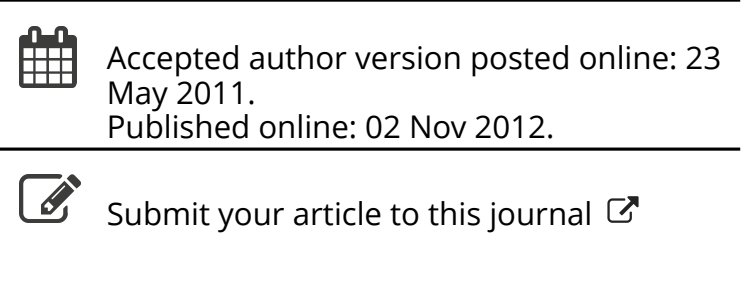

山ll Article views: 303

Citing articles: 5 View citing articles 5 


\title{
DIVERSE ELEMENTS IN HERBAL TEA PRODUCTS CONSUMED IN SERBIA USING INDUCTIVELY COUPLED PLASMA MASS SPECTROMETRY
}

\author{
Slavica Razic ${ }^{1}$ and Vesna Kuntic ${ }^{2}$ \\ ${ }^{1}$ Department of Analytical Chemistry, Faculty of Pharmacy, University of \\ Belgrade, Vojvode Stepe, Belgrade, Serbia \\ ${ }^{2}$ Department of Physical Chemistry, Faculty of Pharmacy, University of Belgrade, \\ Vojvode Stepe, Belgrade, Serbia
}

Nine elements ( $\mathrm{Fe}, \mathrm{Cu}, \mathrm{Mn}, \mathrm{Zn}, \mathrm{As}, \mathrm{Cd}, \mathrm{Sn}, \mathrm{Hg}$, and $\mathrm{Pb}$ ) were determined in 8 teas and 25 herbal teas widely consumed in Serbia for medical purposes. Green, black, peppermint, chamomile, cranberry, sage, rosehip, uva, senna, marigold, and fennel teas were investigated. Microwave-assisted acid digestion was used for all of the samples, and the element contents were determined by inductively coupled plasma mass spectrometry. From all of the determined microelements, the highest content was that of Mn, 2912.8 and $2541.8 \mathrm{mg} / \mathrm{kg}$ of dry matter in the black and green tea, respectively. The contents of toxic elements (As, Cd, and $\mathrm{Pb}$ ) were below the maximum permissible levels, except for one brand of peppermint tea in which the level of Cd was $8.61 \mathrm{mg} / \mathrm{kg}$, much higher than the allowed $0.3 \mathrm{mg} / \mathrm{kg}$.

Keywords: Minor and trace elements, Herbal tea products, ICP-MS.

\section{INTRODUCTION}

Tea is one of the most popular beverages and is consumed by over two-thirds of the world's population. Numerous studies investigate the benefit of tea in reducing the incidence of several diseases, heart diseases, and cancer, in particular. According to general surveys of the work on the medicinal value and beneficial health effects of tea consumption, the major valuable effects of drinking tea are its antioxidative activity and its ability to reduce ischemic heart diseases ${ }^{[1,2]}$ as well as protective effects against a range of cancers. ${ }^{[3,4]}$ The chemical composition of tea is very complex and consists of flavonoids, alkaloids, enzymes, minerals, trace elements, and others. Many of these elements influence the taste of the tea infusion, play a vital role in metabolic processes, and are essential for the general well being of humans. Deficiency or excess of these elements may cause disease and/or be deleterious to health. ${ }^{[5]}$ Heavy metals, such as $\mathrm{Hg}, \mathrm{As}, \mathrm{Pb}$, and $\mathrm{Cd}$, which are present in some herbs can severely damage the haemopoietic, immune, nervous, and reproductive systems. As these elements cannot be completely excreted from the body, they will accumulate and finally have an impact on health. ${ }^{[6]}$

The level of essential elements in plants is conditional, the content being affected by the geochemical characteristics of the soil and by the ability of plants to accumulate

Received 14 May 2010; accepted 17 September 2010.

Address correspondence to Vesna Kuntic, Department of Physical Chemistry, Faculty of Pharmacy, University of Belgrade, Vojvode Stepe 450, Belgrade 11000, Serbia. E-mail: vesna.kuntic@pharmacy.bg.ac.rs 
selectively some of these elements. ${ }^{[7]}$ During growing and processing, medicinal herbs may be easily contaminated. Therefore, the analysis of the metal content, especially of toxic heavy metals, is crucial in the quality control of herb material in order to protect consumers from contamination. Although traditional medicine plays an important role in the general state of the health of a population, many medicinal herbs and their mixtures can present a health risk if toxic elements that are hazardous to humans are present at high concentrations. ${ }^{[8]}$ However, there are no standards for medical raw plant materials that establish the tolerance levels of metals in such materials. The World Health Organization reports maximum permissible levels in raw plant materials only for $\mathrm{As}, \mathrm{Cd}$, and $\mathrm{Pb}$, which amount to $1.0,0.3$, and $10 \mathrm{mg} / \mathrm{kg}$, respectively.

Due to the importance of the minerals present in tea, many different methods have been developed to determine their levels in herbs and tea infusions, but inductively coupled plasma emission spectrometry (ICP-AES) and inductively coupled plasma mass spectrometry (ICP-MS) are fast becoming the techniques of choice for the determination of diverse elements in plant samples, even at trace or ultra trace levels. ${ }^{[9-13]}$ ICP-MS has the widest linear range (nine orders of magnitude), the highest sensitivity, and lowest detection limit for metals, as well as the ability to measure rapidly and accurately multiple elements simultaneously. In this study, nine elements from different tea products commercially available on the Serbian market were analyzed using the ICP-MS method. Microwave-assisted acid digestion was applied for sample preparation. From the obtained data, the importance of tea as a dietary source of minerals and of the risk due to the presence of toxic elements was confirmed.

\section{MATERIALS AND METHODS}

\section{Material}

Samples of green, black, peppermint, chamomile, cranberry, sage, rosehip, uva, senna, marigold, and fennel teas were supplied as tea bags (each containing $2 \mathrm{~g}$ of raw material) or as loose materials from local supermarkets in Serbia. Several of the most widely accepted and most frequently consumed and commercially available brand names of each herbal product were selected. The samples were ground into powder with an agate pestle and mortar for homogenisation before further preparation. An identification code was assigned to each sample (Table 1). A short description of the samples is presented in Table 1.

\section{Equipment}

The ICP-MS instrument (Model Elan 9000, Perkin Elmer, Waltham, MA, USA) was equipped with a dynamic reaction cell to eliminate polyatomic interferences. Nebulizer: Babington nebulizer, Spray chamber: Quartz Scott-type, Peltierthermostatted to $2 \pm 0.1^{\circ} \mathrm{C}$; Torch: Quartz, $2.5 \mathrm{~mm}$ i.d.; interface: Ni cone. The operating conditions for the ICP-MS instrument are: nebulizer Ar flow: $0.83 \mathrm{~L} / \mathrm{min}$; auxiliary Ar flow: $1.20 \mathrm{~L} / \mathrm{min}$; plasma Ar flow: $15 \mathrm{~L} / \mathrm{min}$; sample uptake rate: $1 \mathrm{~mL} / \mathrm{min}$; lens voltage: $10.75 \mathrm{~V}$; ICP RF power: $1175 \mathrm{~W}$; analog stage voltage: $-2100 \mathrm{~V}$; pulse stage voltage $1050 \mathrm{~V}$; cell rod offset CRO: -14 . The samples were weighed using an analytical balance (XB 220A, Precisa, Dietikon, Switzerland) and subjected to microwave digestion in a microwave oven (Multiwave 3000, Anton Paar, Graz, Austria). Deionised water, conductivity of $0.02 \mu \mathrm{S} / \mathrm{cm}$ (Milli-Q ultrapure water system, Bedford, MA, USA) was used throughout. 
Table 1 Analysed tea samples.

\begin{tabular}{|c|c|c|c|c|}
\hline No. & Sample code & Class & Packaging & Indications \\
\hline \multicolumn{5}{|c|}{ Theae (Camelliae) folium } \\
\hline 1. & $\mathrm{G} 1$ & Green & Tea bags & \multirow{10}{*}{$\begin{array}{l}\text { Potent antioxidant, reduces the risk of } \\
\text { cardiovascular disease and cancer, as well } \\
\text { as having a beneficial impact on bone } \\
\text { density, cognitive function, dental cavities, } \\
\text { and kidney stones }\end{array}$} \\
\hline 2. & G2 & Green & Tea bags & \\
\hline 3. & G3 & Green & Tea bags & \\
\hline 4. & G4 & Green (Mint) & Tea bags & \\
\hline 5. & G5 & Green (Jasmine) & Tea bags & \\
\hline 6. & G6 & Green (China) & Loose tea & \\
\hline 7. & G7 & Green (Japan) & Loose tea & \\
\hline 8. & G8 & Green & Loose tea & \\
\hline 9. & G9 & Green & Loose tea & \\
\hline 10. & G10 & Green & Loose tea & \\
\hline 11. & B1 & Black (Indian) & Tea bags & \multirow{8}{*}{$\begin{array}{l}\text { Potent antioxidant, relieves diarrhoea, lowers } \\
\text { cholesterol levels, has a special therapeutic } \\
\text { effect on gastric/intestinal discomforts }\end{array}$} \\
\hline 12. & B2 & Black & Tea bags & \\
\hline 13. & B3 & Black & Tea bags & \\
\hline 14. & B4 & Black (Ceylon) & Tea bags & \\
\hline 15. & B5 & Black & Tea bags & \\
\hline 16. & B6 & Black (Ceylon) & Tea bags & \\
\hline 17. & B7 & Black (Russian) & Tea bags & \\
\hline 18. & B8 & Black & Tea bags & \\
\hline \multicolumn{5}{|c|}{ Menthae piperitae folium } \\
\hline 19. & $\mathrm{P} 1$ & Peppermint & Tea bags & \multirow{4}{*}{$\begin{array}{l}\text { Has a high menthol content, relieves irritable } \\
\text { bowel syndrome, nausea and vomiting, } \\
\text { diarrhoea, headaches, and baby colic }\end{array}$} \\
\hline 20. & $\mathrm{P} 2$ & Tea bags & & \\
\hline 21. & P3 & Tea bags & & \\
\hline 22. & $\mathrm{P} 4$ & Loose tea & & \\
\hline 23. & $\mathrm{C} 1$ & Chamomillae flos & Tea bags & \multirow{2}{*}{$\begin{array}{l}\text { Anti-inflammatory, spasmolytic, vulnerary, } \\
\text { antimicrobial, mild sedative, carminative, } \\
\text { antiseptic, anticatarrhal }\end{array}$} \\
\hline 24. & $\mathrm{C} 2$ & Chamomile & Loose tea & \\
\hline 25. & $\mathrm{Cr} 1$ & Vaccinii macrocarponi fructus & Tea bags & \multirow[t]{2}{*}{ Uroantiseptic } \\
\hline 26. & $\mathrm{Cr} 2$ & Cranberry & Tea bags & \\
\hline 27. & $\mathrm{Sa}$ & Salviae folium sage & Loose tea & $\begin{array}{l}\text { Refreshes the body, fights virus and bacteria, } \\
\text { anti-inflammatory, dental caries }\end{array}$ \\
\hline 28. & $\mathrm{R} 1$ & Rosae caninae pseudofructus & Tea bags & \multirow{2}{*}{$\begin{array}{l}\text { Rich source of vitamin } \mathrm{C} \text {, used for colds and } \\
\text { influenza }\end{array}$} \\
\hline 29. & $\mathrm{R} 2$ & Rosehip & Loose tea & \\
\hline 30. & $\mathrm{U}$ & Uvae ursi folium uva & Tea bags & Antibacterial, uroantiseptic \\
\hline 31. & $\mathrm{Se}$ & Sennae folium senna & Loose tea & Relieves occasional constipation \\
\hline 32. & M & Calendulae flos marigold & Loose tea & $\begin{array}{l}\text { A cleansing and detoxifying herb with } \\
\text { antifungal, antiviral, and antibiotic activity }\end{array}$ \\
\hline 33. & $\mathrm{~F}$ & Foeniculi fructus fennel & Loose tea & $\begin{array}{l}\text { Analgesic, antidepressive, anti-inflammatory, } \\
\text { digestive disorders, spasmolytic }\end{array}$ \\
\hline
\end{tabular}

\section{Reagents and Standard Solutions}

All reagents were produced by Merck (Darmstadt, Germany). Nitric and hydrochloric acid, suprapure, trace metal grade were used. A rhodium standard solution, used as the internal standard (IS), was obtained by diluting $\mathrm{Rh}\left(\mathrm{NO}_{3}\right)_{3}$ in $0.5 \mathrm{M} \mathrm{HNO}_{3}$ to attain a concentration of $10 \mathrm{mg} / \mathrm{L}$ and thereafter diluted ten times. For calibration purposes, standard stock solutions ( $c=1002 \pm 2 \mathrm{mg} / \mathrm{L}$ ) of each element were prepared by diluting the appropriate amount of $\mathrm{Pb}\left(\mathrm{NO}_{3}\right)_{2}, \mathrm{Fe}\left(\mathrm{NO}_{3}\right)_{2}, \mathrm{H}_{3} \mathrm{AsO}_{4}, \mathrm{Zn}\left(\mathrm{NO}_{3}\right)_{2}, \mathrm{Cu}\left(\mathrm{NO}_{3}\right)_{2}$, or $\mathrm{Mn}\left(\mathrm{NO}_{3}\right)_{2}$ in $0.5 \mathrm{M} \mathrm{HNO}_{3}, \mathrm{Hg}\left(\mathrm{NO}_{3}\right)_{2}$ in $2 \mathrm{M} \mathrm{HNO}_{3}$, and $\mathrm{SnCl}_{4}$ in $2 \mathrm{M} \mathrm{HCl}$. Calibration mixed standard solutions were prepared by diluting standard stock solutions with $2 \% \mathrm{HNO}_{3}$ to an obtained 
concentration of $3000,2000,1500,1000,500,250,100,50$, and $10 \mu \mathrm{g} / \mathrm{L}$. To each of the working standard solutions, the IS was added to attain a final concentration of $10 \mu \mathrm{g} / \mathrm{L}$. For the standard addition method, three aliquots of mixed standard $(250,500$, and $750 \mu \mathrm{L})$ were used for spiking the samples. SRM 2977, NIST, mussel tissue (organic contaminants and trace elements) was used for validation purposes.

\section{Sample Solutions}

Tea samples were prepared by microwave-assisted acid digestion. The high temperature assured fast and complete digestion. The closed system in which the containers were operated prevented the loss of volatile elements like As and $\mathrm{Hg}$. To $0.5 \mathrm{~g}$ of each tea sample, $7 \mathrm{~mL}$ conc. $\mathrm{HNO}_{3}$ was added. The digestion was performed according to the temperature programmes described elsewhere. ${ }^{[14]}$ After cooling, the solutions were quantitatively transferred into $50 \mathrm{~mL}$ volumetric flasks. Into each flask, $500 \mu \mathrm{L}$ of IS was added and diluted with deionised water to volume. At least one sample blank, containing the same amounts of acid, was processed along with each set of samples.

\section{RESULTS AND DISCUSSION}

Medicinal herbs traditionally consumed in Serbia as teas and herbal teas are listed in Table 1. Thus, the content of minor and trace elements is crucial for the evaluation of dietary information. In the present work, the concentrations of nine elements in herb teas, that is, green (Camellia sinensis unfermented), black (Camellia sinensis, fermented), peppermint (Menthae piperitae), chamomile (Matricaria chamomilla), cranberry (Vaccinii macrocarponi), sage (Salvia officinalis), rosehip (Rosae caninae), uva (Arctostaphylos uva ursi), senna (Cassia angustifolia), marigold (Calendula officinalis), and fennel (Foeniculum vulgare) teas, were determined.

\section{Determination of Elements by ICP-MS}

ICP-MS provides a fast multi-elemental analysis having several advantages over techniques commonly used for trace-to-ultra trace element analysis, such as ICP-OES, FAAS, GFAAS, and HGAAS. ${ }^{[15-19]}$ Higher sensitivity, lower detection limits, and simultaneous measurements of series of elements make this technique superior for both total elements quantification and speciation analysis. All the elements determined in this study were measured in the same analytical run and all the samples and standard reference materials were digested using the same method.

In order to check and prove the reliability of the method, several validation steps were applied. The accuracy was tested by analysing a standard reference material. The recovery values, for all the elements studied in this work, were found to be in the range from 97.2 to $98.9 \%$ (Table 2). In order to investigate the matrix influence, the standard addition method was applied and the validation procedure was continued by checking significant analytical parameters. A linear relationship was observed in the concentration range $0.010-3000 \mu \mathrm{g} / \mathrm{L}$. Concentration in the sample was determined from the calibration curve constructed using multi-element standard solutions. Correlation coefficients were very high $(r=0.9999)$ for all investigated elements. The detection limit, defined as the concentration of each element corresponding to three times the standard deviation from the analysis of blanks $(n=10)$, was $1 \mu \mathrm{g} / \mathrm{L}$. The limit of quantification was determined 
Table 2 Assessment of the accuracy and precision of the method by using standard reference material.

\begin{tabular}{lccc}
\hline Element & $\begin{array}{c}\text { Found value, } \\
\mathrm{mg} / \mathrm{kg}\end{array}$ & $\begin{array}{c}\text { Certified value, } \\
\mathrm{mg} / \mathrm{kg}\end{array}$ & Recovery, \% \\
\hline $\mathrm{Fe}$ & 267 & $274 \pm 18$ & 97.4 \\
$\mathrm{Cu}$ & 9.21 & $9.42 \pm 0.52$ & 97.8 \\
$\mathrm{Mn}$ & 23.67 & $23.93 \pm 0.29$ & 98.9 \\
$\mathrm{Zn}$ & 131 & $135 \pm 5$ & 96.7 \\
$\mathrm{As}$ & 8.64 & $8.83 \pm 0.91$ & 97.9 \\
$\mathrm{Cd}$ & 0.176 & $1.47 \pm 0.27$ & 98.4 \\
$\mathrm{Sn}$ & 1.45 & $0.101 \pm 0.004$ & 98.3 \\
$\mathrm{Hg}$ & 0.098 & $2.27 \pm 0.13$ & 97.2 \\
$\mathrm{~Pb}$ & 2.23 & & 98.2 \\
\hline
\end{tabular}

for each calibration curve and the highest value of $3 \mu \mathrm{g} / \mathrm{L}$ was adopted as being quite satisfactory for the requirements of this work. The precision of the method applied in this work was also estimated by calculation of the repeatability (up to $1.8 \%$ ) and reproductively (up to $7.9 \%$ ) for each element. The uncertainty of the estimates was based on repeated analysis of samples and the reference material. After the validation procedure was completed, the concentrations of all the studied elements were calculated and the results are presented in Table 3. The Grubbs test ${ }^{[20]}$ was applied to identify outliers. The outliers, marked with an asterisk in Table 3, were excluded from further statistical analysis.

\section{Metal Content}

All of the investigated medicinal herbs contained significant values of the essential elements ( $\mathrm{Fe}, \mathrm{Cu}, \mathrm{Mn}$, and $\mathrm{Zn}$ ). However, the content of essential elements varied significantly between different species, but also among the same species. Of the essential elements, Mn was the metal with the highest content with an average value of $656.8 \mathrm{mg} / \mathrm{kg}$, while $\mathrm{Cu}$ had the lowest average value of $11.38 \mathrm{mg} / \mathrm{kg}$. Iron content in different herbs varied in a broad range from $1.63 \mathrm{mg} / \mathrm{kg}$ (fennel) to $1002 \mathrm{mg} / \mathrm{kg}$ (marigold), with an average value of $361.2 \mathrm{mg} / \mathrm{kg}$. The average Fe concentrations found in all of the green and black tea samples were 358.7 and $271 \mathrm{mg} / \mathrm{kg}$, respectively, which correspond to those reported by Fernandez-Caceres, ${ }^{[10]}$ who determined 318 and $319 \mathrm{mg} / \mathrm{kg}$, respectively. The level of $\mathrm{Fe}$ in the tea products is in agreement with its content in other medical herbs. ${ }^{[9,13]}$

As essential trace elements, $\mathrm{Cu}$ and $\mathrm{Zn}$ are important parts of the enzymes superoxide dismutase, lysyl oxidase, and ceruloplasmin, which protect cells from oxidative damage. The dietary habits and the environmental conditions may partly influence the levels of these trace elements in tissues and biological fluids as well, consequently influencing their participation in numerous biochemical mechanisms. ${ }^{[6]} \mathrm{Cu}$ and $\mathrm{Zn}$ were present in the range of $0.48-24.2 \mathrm{mg} / \mathrm{kg}$ and $0.07-66.4 \mathrm{mg} / \mathrm{kg}$, respectively. The average $\mathrm{Zn}$ levels in all herbs was two times higher $(24.3 \mathrm{mg} / \mathrm{kg})$ than the $\mathrm{Cu}$ level $(11.4 \mathrm{mg} / \mathrm{kg})$. Zinc reached a higher value in sage, which was also found by Basgel, ${ }^{[13]}$ and $\mathrm{Cu}$ reached higher values in green (G9) and black (B4) tea, with average values of $16.37 \mathrm{mg} / \mathrm{kg}$ and $15.54 \mathrm{mg} / \mathrm{kg}$, respectively, which correspond to the values found in Fernandez-Caceres et al. ${ }^{[10]}$

$\mathrm{Mn}$ in the herbs varied from $0.365 \mathrm{mg} / \mathrm{kg}$ (G6 and G7) to $2912.8 \mathrm{mg} / \mathrm{kg}$ (B1). Higher contents were found in the black tea (average value of all B samples was $1069.3 \mathrm{mg} / \mathrm{kg}$ ) and rosehip $(1281 \mathrm{mg} / \mathrm{kg}$ ) samples, which are significantly higher than the average content 
Table 3 Element content in tea samples $(\mathrm{mg} / \mathrm{kg})$ expressed on dry basis.

\begin{tabular}{|c|c|c|c|c|c|c|c|c|c|c|}
\hline No. & Sample & $\mathrm{Fe}$ & $\mathrm{Cu}$ & $\mathrm{Mn}$ & $\mathrm{Zn}$ & As & $\mathrm{Cd}$ & $\mathrm{Sn}$ & $\mathrm{Hg}$ & $\mathrm{Pb}$ \\
\hline 1 & G1 & 358.7 & 19.5 & 1189.6 & 27.8 & 0.265 & 0.108 & 23.3 & 0.132 & 2.79 \\
\hline 2 & G2 & 111.6 & 6.49 & 63.4 & 8.88 & 0.061 & 0.050 & ND & ND & 0.929 \\
\hline 3 & G3 & 395.7 & $64.3^{*}$ & 2541.8 & 63.1 & 0.26 & 0.002 & 20.1 & ND & 1.34 \\
\hline 4 & G4 & 364.6 & 15.6 & 1481.2 & 15.6 & 0.074 & 0.014 & 4.13 & 0.056 & 0.350 \\
\hline 5 & G5 & 322.0 & 11.2 & 1455.6 & 9.65 & 0.055 & 0.010 & 5.02 & 0.036 & 0.551 \\
\hline 6 & G6 & 669.6 & 21.8 & 0.365 & 26.9 & 0.213 & 0.089 & 10.0 & ND & 2.34 \\
\hline 7 & G7 & 315.9 & 16.9 & 0.365 & 28.5 & 0.081 & 0.128 & 5.75 & ND & 3.53 \\
\hline 8 & G8 & 715.8 & 13.9 & 672.6 & 28.3 & 0.311 & 0.249 & 12.1 & ND & 1.26 \\
\hline 9 & G9 & 888.7 & 24.2 & 1160.3 & 34.9 & 0.367 & 0.107 & 4.92 & ND & 2.0 \\
\hline 10 & G10 & 496.2 & 17.8 & 1798.2 & 31.2 & 0.159 & 0.061 & 9.97 & ND & 2.04 \\
\hline 11 & B1 & 392.7 & $63.6^{*}$ & 2912.8 & 57.4 & 0.26 & 0.006 & 13.7 & 0.058 & 1.38 \\
\hline 12 & B2 & 490.0 & 19.4 & 588.8 & 24.5 & 0.099 & 0.038 & 13.5 & 0.162 & 1.32 \\
\hline 13 & B3 & 150.1 & 9.68 & 36.6 & 15.9 & 0.102 & 0.061 & 1.56 & 0.01 & 0.324 \\
\hline 14 & B4 & 216.1 & 20.2 & 954.3 & 32.4 & 0.264 & 0.095 & 15.1 & 0.091 & 2.09 \\
\hline 15 & B5 & 446.0 & 16.7 & 864.0 & 23.4 & 0.151 & 0.017 & 12.3 & 0.008 & 0.620 \\
\hline 16 & B6 & 786.2 & 18.7 & 1501.2 & 29.7 & 0.359 & 0.029 & 22.2 & $0.736^{*}$ & 1.29 \\
\hline 17 & B7 & 453.7 & 12.8 & 802.1 & 19.9 & $0.893^{*}$ & 0.025 & 7.73 & ND & 1.22 \\
\hline 18 & B8 & 218.9 & 11.3 & 894.4 & 15.9 & 0.286 & 0.020 & 3.73 & ND & 0.891 \\
\hline 19 & $\mathrm{P} 1$ & 237.5 & 8.43 & 343.1 & 23.6 & 0.086 & 0.098 & 13.8 & 0.007 & 0.364 \\
\hline 20 & $\mathrm{P} 2$ & 345.1 & 8.96 & 214.7 & 20.1 & 0.115 & 0.076 & 2.95 & 0.010 & 0.381 \\
\hline 21 & P3 & 264.2 & 6.96 & 229.3 & 0.069 & 0.025 & $8.61^{*}$ & 0.009 & $0.530^{*}$ & $9.97^{*}$ \\
\hline 22 & $\mathrm{P} 4$ & 721.9 & 11.8 & 120.4 & 21.8 & 0.155 & 0.040 & 4.34 & 0.014 & 0.580 \\
\hline 23 & $\mathrm{C} 1$ & 506.7 & 8.85 & 69.3 & 24.4 & 0.337 & 0.132 & 4.28 & 0.001 & 0.856 \\
\hline 24 & $\mathrm{C} 2$ & 146.7 & 7.26 & 7098.7* & 21.9 & 0.409 & 0.179 & 3.16 & 0.025 & 0.707 \\
\hline 25 & $\mathrm{Cr} 1$ & 274.0 & 9.45 & 102.1 & 43.9 & 0.052 & 0.031 & $426.3^{*}$ & ND & 1.52 \\
\hline 26 & $\mathrm{Cr} 2$ & 86.0 & 1.19 & 52.3 & 2.98 & 0.035 & 0.011 & ND & $\mathrm{ND}$ & 0.063 \\
\hline 27 & $\mathrm{Sa}$ & 40.9 & 9.64 & 26.5 & 66.4 & 0.046 & 0.054 & 10.4 & 0.002 & 2.20 \\
\hline 28 & $\mathrm{R} 1$ & 464.5 & 14.9 & 1585.9 & 13.7 & 0.101 & 0.030 & 5.01 & ND & 1.62 \\
\hline 29 & $\mathrm{R} 2$ & 141.0 & 6.00 & 976.2 & 24.6 & 0.088 & 0.054 & 27.6 & ND & 0.103 \\
\hline 30 & $\mathrm{U}$ & 183.8 & 3.39 & 15.7 & 29.9 & 0.031 & 0.012 & 0.77 & ND & 0.549 \\
\hline 31 & $\mathrm{Se}$ & 465.7 & 12.4 & 41.6 & 15.4 & 0.286 & 0.011 & 15.7 & 0.017 & 0.423 \\
\hline 32 & M & 1002.0 & 7.97 & 325.9 & 23.6 & 0.128 & 0.058 & 26.2 & 0.006 & 1.21 \\
\hline 33 & $\mathrm{~F}$ & 1.63 & 0.477 & 1.42 & 1.33 & 0.008 & 0.002 & 1.25 & 0.007 & 0.0005 \\
\hline
\end{tabular}

*Outliers.

ND: not detected.

of all samples, i.e., $656.8 \mathrm{mg} / \mathrm{kg}$. These results are in agreement with the result found by Fernandez-Caceres et al., ${ }^{[10]}$ who determined $824.8 \mathrm{mg} / \mathrm{kg}$, but significantly higher than the values found by Basgel, ${ }^{[13]}$ who determined $\mathrm{Mn}$ in the range from $32-244 \mathrm{mg} / \mathrm{kg}$. The high content of Mn could be ascribed as being the result of plant cultivation in industrial and residential sites rich in $\mathrm{Mn}$, due to its use as a fuel additive. Since Mn is essential for the human endocrine, nervous, and enzyme systems and is a key element in most enzymes, the consumption of black and rosehip teas could support normal metabolism.

The contents of the toxic elements $\mathrm{As}, \mathrm{Cd}$, and $\mathrm{Pb}$ were below the maximum permissible levels for all samples. Although the $\mathrm{Cd}$ level of $8.61 \mathrm{mg} / \mathrm{kg}$ and $\mathrm{Pb}$ level of $9.97 \mathrm{mg} / \mathrm{kg}$ in the peppermint P3 sample were discarded as outliers for the descriptive statistics, they may indicate that the plant had been growing in a potentially polluted industrial environment. Mercury is not detected in 14 samples. The higher concentrations of $\mathrm{Hg}$ in B6 and P3 samples can be observed, but it is still under the maximum permissible 
level. ${ }^{[11]}$ Tin is not usually determined in medical herbs. According to the limited literature data, ${ }^{[9]}$ the levels of $\mathrm{Sn}$ in peppermint and nettle tea were below the detection limit. In the present study, Sn could not be detected in some samples (G2, Cr2), but showed a variety of values in the other samples from $0.009 \mathrm{mg} / \mathrm{kg}$ (P3 sample) to $26.2 \mathrm{mg} / \mathrm{kg}$ (M sample), with an average value of $9.45 \mathrm{mg} / \mathrm{kg}$. It is already known that the greatest increase in dietary $\mathrm{Sn}$ is caused by the release of Sn from cans or plastic containers. ${ }^{[5]}$ Thus, the high concentration of $\mathrm{Sn}$ in the marigold sample may be due to its improper storage.

\section{CONCLUSIONS}

In this study, 8 teas and 25 herbal teas widely consumed in Serbia were investigated. The content of essential elements varied significantly between the samples. Some of them ( $\mathrm{M}$ and G9) could be used as beneficial sources for Fe, while G3 and B1 were particularly rich in $\mathrm{Mn}$. The concentration of toxic elements ( $\mathrm{As}, \mathrm{Cd}$, and $\mathrm{Hg}$ ) did not exceed the maximum permissible values, although in some peppermint products (P3), the levels of $\mathrm{Cd}$ were over the standard limited value for medicinal plants. Considering that tea samples with unknown geographical origins were investigated, it was not possible to find relationships between the metal contents and the growth environments. Giving the general trend toward a healthy lifestyle, which implies increased consumption of natural products, and the fact that plants are nowadays grown in increasingly polluted, industrial and urban areas, reliable and efficient quality control methods that enable fast screening for toxic metals in herbs are required.

\section{ACKNOWLEDGMENT}

The authors gratefully acknowledge the financial support from the Ministry of Science and Environment of the Republic of Serbia, grants No. III43009 and No. 172041. The authors also wish to thank Biljana Marosanovic and SP LABORATORIJA A.D. C.E.O. of Instrumental Analysis Department, Becej, Serbia, for assistance in the measurements.

\section{REFERENCES}

1. Hertog, M.G.L.; Feskens, E.J.M.; Hollman, P.C.H.; Katan, M.B.; Kromhout, D. Dietary antioxidant flavonoids and risk of coronary heart disease. Lancet 1993, 342, 1007-1011.

2. Verena, S.; Lorenz, M.; Stangl, K. The role of tea and tea flavonoids in cardiovascular health. Molecular Nutrition \& Food Research 2006, 50, 218-228.

3. Hamilton-Miller, J.M. Anti-carcinogenic properties of tea (Camellia sinensis). Journal of Medical Microbiology 2001, 50 (4), 299-302.

4. Smith, D.M.; Dou, Q.P. Green tea polyphenol epigallocatechin inhibits DNA replication and consequently induces leukemia cell apoptosis. International Journal of Molecular Medicine 2001, 7 (6), 645-652.

5. Mills, C.F. The detection of trace element deficiency and excess in man and farm animals. Proceedings of the Nutrition Society 1974, 33, 267-274.

6. Jacob, R.A. Trace elements. In: Textbook of Clinical Chemistry; Tietz, N.W.; Ed.; W.B. Saunders: Philadelphia, PA, 1986.

7. Bin, C.; Xiaouru, W.; Lee, F.S.C. Pyrolysis coupled with atomic absorption spectrometry for determination of mercury in Chinese medicinal materials. Analytica Chimica Acta 2001, 447, 161-169. 
8. Lekouch, N.; Sedki, A.; Nejmeddine, A.; Gamon, S. Lead and traditional Moroccan pharmacopoeia. Science of the Total Environment 2001, 280, 39-43.

9. Lozak, A.; Soytyk, K.; Ostapczuk, P.; Fijayek, Z. Determination of selected trace elements in herbs and their infusions. Science of the Total Environment 2002, 289, 33-40.

10. Fernandez-Caceres, P.L.; Martın, M.J.; Pablos, F.; Gonzalez, A.G. Differentiation of tea (Camellia sinensis) varieties and their geographical origin according to their metal content. Journal of Agricultural and Food Chemistry 2001, 49, 4775-4779.

11. Nookabkaew, S.; Rangkadilok, N.; Satayavivad, J. Determination of trace elements in herbal tea products and their infusions consumed in Thailand. Journal of Agricultural and Food Chemistry 2006, 54, 6939-6944.

12. Fernandez, P.L.; Pablos, F.; Martın, M.J.; Gonzalez, A.G. Multi-element analysis of tea beverages by inductively coupled plasma atomic emission spectrometry. Food Chemistry 2002, 76, 483-489.

13. Basgel, S.; Erdemoglu, S.B. Determination of mineral and trace elements in some medicinal herbs and their infusion consumed in Turkey. Science of the Total Environment 2006, 359, $82-89$.

14. SW-846. EPA method 3052: Microwave assisted acid digestion of siliceous and organically based matrices. In: Test Methods for Evaluating Solid Waste, 3rd Ed.; 3rd Update; U.S. Environmental Protection Agency: Washington, DC, 1995.

15. Ražić, S.; Onjia, A.; Potkonjak, B. Trace elements analysis of Echinacea purpurea-herbal medicinal. Journal of Pharmaceutical and Biomedical Analysis 2003, 33, 845-850.

16. Ražić, S.; Onjia, A.; Đogo, S.; Slavković, L.; Popović, A. Determination of metal content in some herbal drugs-Empirical and chemometric approach. Talanta 2005, 67, 233-239.

17. Kosanovic, M.; Hasan, Y.M.; Petroianu, G.; Marzouqi, A.; Abdularhman, O.; Adem A. Assessment of essential and toxic mineral elements in bitter gourd (Momordica Charantia) fruit. International Journal of Food Properties 2009, 12, 766-773.

18. Ražić, S.S.; Đogo, S.M.; Slavković, L.J. Multivariate characterization of herbal drugs and rhizosphere soil samples according to their metallic content. Microchemical Journal 2006, 84, 93-101.

19. Ražić, S.; Đogo, S.; Slavković, L. Inorganic analysis of herbal drugs. Part II. Plant and soil analysis-Diverse bioavailability and uptake of essential and toxic elements. Journal of Serbian Chemical Society 2006, 71 (10), 1095-1105.

20. Grubbs, F.E. Procedure for detecting outlying observations in samples. Technometrics 1969, $11(1), 1-21$. 